Språkspalten

\title{
Kronisk utmattelsessyndrom
}

\section{Kronisk utmattelsessyndrom blir foretrukket term for «chronic fatigue syndrome» i Tidsskriftet.}

I 2002 gjorde jeg rede for hvorfor «chronic fatigue syndrome» burde oversettes med kronisk tretthetssyndrom på norsk (1). To år senere argumenterte Wyller \& Wyller for at «fatigue» ikke burde oversettes med tretthet, men med utmattelse (2-5). En viktig begrunnelse for at Tidsskriftet har brukt betegnelsen kronisk tretthetssyndrom, er at denne termen også brukes i de andre nordiske land (3) - på dansk «kronisk træthedssyndrom», på svensk «kroniskt trötthetssyndrom (1). Dette er fremdeles tilfellet (6).

Vi registrerer imidlertid at språkbruken i Norge har gått i retning av kronisk utmattelsessyndrom. I f.eks. omtalen på Wikipedia står det at «De fleste med tilstanden har vanskelig for å kjenne seg igjen i begrepet «tretthet», og kronisk utmattelsessyndrom er den betegnelsen som bør benyttes.» (7). I Store medisinske leksikon, som nå ligger på nettet under Store norske leksikon, anføres de samme argumentene men forklaringen på utmattelsessyndrom ligger under tretthetssyndrom (8).

I Tidsskriftet vil vi heretter bruke uttrykket kronisk utmattelsessyndrom. Tilstanden omtales av Torunn Bjørkum og medarbeidere i dette nummer av Tidsskriftet (9).

\section{Erlend Hem}

erlend.hem@medisin.uio.no

Tidsskriftet

\section{Litteratur}

1. Hem E. Kronisk tretthetssyndrom på norsk. Tidsskr Nor Lægeforen 2002; 122: 1710.

2. Wyller VB, Wyller TB. Kronisk utmattelsessyndrom. Tidsskr Nor Lægeforen 2004; 124: 2388.

3. Hem E. Loge JH. Kronisk tretthetssyndrom - adekvat betegnelse. Tidsskr Nor Lægeforen 2004; 124 2388

4. Wyller VB, Wyller TB. Utmattelse - ikke tretthet. Tidsskr Nor Lægeforen 2004; 124: 2802.

5. Hem E, Loge JH. Utmattelse - ikke tretthet. Tilsvar. Tidsskr Nor Lægeforen 2004; 124: 2802.

6. Herlofson J, red. Psykiatri. Lund: Studentlitteratur, 2009: 464.

7. Kronisk utmattelsessyndrom. http://no wikipedia.org/wiki/Kronisk_utmattelsessyndrom (17.5.2009).

8. Malt U. Tretthetssyndrom (SML-artikkel). Store norske leksikon. www.snl.no/.sml_artikkel/tretthetssyndrom (18.5.2009).

9. Bjørkum T, Wang CE, Waterloo K. Pasienterfaringer med ulike tiltak ved kronisk utmattelsessyndrom. Tidsskr Nor Legeforen 2009; 129: 0000-00. 